\title{
Proportional Mortality Ratios among Korean Immigrants to New York City, 1986-1990
}

\author{
Stever D. Stellman
}

\begin{abstract}
BACKGROUND: About 13,000 people immigyated to New York City from the Republic of Korea botween 1986 and 1990 , crating an important whic minority.

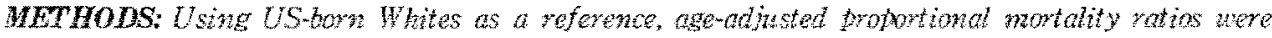
computed for 314 men and 248 women of Korean ancestry born abroad who died in New York City in $1986-90$.

RESULTS: Males had a significant exnes of viral hebatitis, cancer, stroke, and exterial causes: accidents, suicide, and homicide. They had significantly reduced proportional rates of AIDS and heari disease. Mortality failerns uere similar for Korean women, who had significanily increased

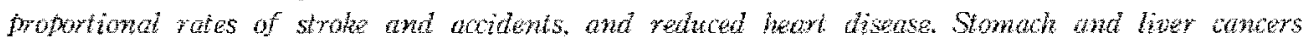
were significantly elevated in both sexes, while female breast cancer was low. There were two male and one femato tuberculosis deaths ( 4 to 7 fold increase), and one Korean woman died of childbirth complications (59-jold increase)

CONCLUSIONS: Excett for vident deaths, these observations resemble known mortality patterns in Korea.
\end{abstract}

Key Words: Immigrants, Korea, New York City, proportional mortality, vital records

Studies of the health of migrant populations serve two important functions: (1) they are an essential survellance tool for informing health authorities of potential problems requiring preventive measures, and (2) careful observations of shifts in patterns of illness in the migrant group towards that of the adopted country can serve to document and quantify the impact of environmental changes on etiol

Received November 9, 1995

Accepted February 7, 1996

Work supported by an NIH Fogarty Senior Irternational Fellowship. Analyses were carried out while the author was a visiting scientist in the Descriptive Epidemiology Programme at the International Agency for Research on Cancer, Lyon, France. Additional support was provided by U.S. National Cancer Institute Grants CA-17613, CA-32617, CA-63021, and CA-68384.

Address reprint request to Steven D. Stellman, Ph.D. M. P.H. American Health Foundation 320 East 43rd Street New York, NY 100/7

Tel. 212-551-252! ogy of some diseases, acute and chronic.

This is the first study of mortality among Koreans in New York City, and covers the five year period 1986 to 1990. During this time period New York experienced a wave of about 13,000 immigrants from the Republic of Korea, and independent estimates from official immigration and birth records suggest a sustained, current growth rate of about $5 \%$ per year for persons of Korean ancestry.

The mortality of Koreans living in Japan has been reported on several occasions ( $\mathrm{Km}$, 1984; Ubukata et al. 1986; Kono et al. 1987\% Ubukata et al. 1987; Shinohara ot al. 1990), and Frerichs et at. (1984) surveyed mortality of Koreans dying in Los Angeles County. However, accurate death rates are not known for The Republic of Korea, which lacks a comprehensive death registration system. Overall mortality patterns have been inferred for Korea through indirect sampling methods (Kim, 1986), and rough estimates of cause-specific 
death rates have been made by the World Health Organization (1990). Cancer mortality in Southwestern Korea was reported in 1980 (Seel, 1980), and a network of hospital cancer registries has been established, from which basic cancer statistics have been published Ministry of Health and Social Affairs, 1988; Kim et al. 1989)

\section{MATERIALS AND METHODS}

This study is based on data recorded on death certificates for all deaths that occurred within New York City during 1986 through 1990. New York City constitutes an independent registra tion area for births and deaths, equivalent to other States. By law, all deaths which occur within New York City must be reported to the Department of Health, irrespective of the birthplace, country of origin, or legal status of the decedent. Reporting is practically $100 \%$ complete, and includes citizens and legal visitors to the United States as well as those who entered unlawfully. Besides cause of death, the New York City death certificate contains information on race, ancestyy (called "descent or origin" prior to 1988), and birthpiace of decedent. Birthplace is coded in the computer file as either State (if born in the U.S.) or as specific country of birth. Sex, dates of birth and death, and other demographic data are coded as well, and underlying cause of death is coded according to the Ninth Revision of the International Classification of Diseases. All items are coded by trained nosologists, and special attention is given to accurate assignment of over 270 possible ancestry and birthplace codes.

For males and females considered separately, two study groups were constructed, consisting of (1) all US-born Whites who died during the years 1986-90, and (2) all persons of Korean ancestry born outside of the United States, and who died in New York City during the same period. The interval chosen is the most recent five-year period for which complete mortality records are available.

Suitable population figures were not available for Korean immigrants to New York
City. Therefore, a statistical method was used that depends only on numerator data. Proportional mortality ratios (PMRs) were formed according to the method described by Breslow and Day (1987). In this method, all deaths were classified by sex, age, and cause, using six age strata: $1 \sim 29$ yr, $30-44$ yr, $45-54 \mathrm{yr}$, $55 \sim 64 \mathrm{yr}, 65 \sim 74 \mathrm{yr}$, and $75+\mathrm{yr}$. Deaths under one year of age were eliminated because they are very few among Koreans, and are subiect to ascertainment biases that do not affect other age groups.

Causes of death were grouped in categories used by the New York City Department of Health in its annual Vital Statistics Summaries New York City Department of Health, 1991). These correspond closely to the "Abbreviated International List" used by the World Health Organization (World Health Organization, 1990). For each cause of death, the ratio within a given age stratum which that cause bears to the total among US Whites is multiplied by the total number of Korean deaths in that age stratum, to produce an expected number of deaths. The total observed deaths divided by the total expected deaths summed over all six age groups yields the age-adjusted PMR for the cause in question. The Poisson statistic is used to compare observed with expected deaths, and $95 \%$ confidence intervais are computed using the algorithm of Rothman and Boice (1982).

\section{RESULTS}

During $1986-90$ a total of 65,251 US-born White males and 63,006 US-born White females died in New York City. In the same period, 314 males and 248 females of Korean ancestry who had been born outside the United States also died; all but 13 of these persons were born in Korea. These deaths represent $95 \%$ of all persons of Korean ancestry who died in New York City.

Table 1 shows the distribution of age at death for both ethnic groups, by sex. Age at feath largely reflects the age distribution of the surviving population, and shows dramati- 
Mortality in Korean Immigrants

Table 1. Distribution of age at death for US-horn Whites and foreign-born Koreans New York City 1986 1990

\begin{tabular}{|c|c|c|c|c|c|c|c|c|}
\hline \multirow[b]{3}{*}{ Age, $\mathrm{Yr}$} & \multicolumn{4}{|c|}{ Males } & \multicolumn{4}{|c|}{ Females } \\
\hline & \multicolumn{2}{|c|}{ US White } & \multicolumn{2}{|c|}{ Korean } & \multicolumn{2}{|c|}{ US White } & \multicolumn{2}{|c|}{ Korean } \\
\hline & $\begin{array}{l}\text { Number } \\
\text { of deaths }\end{array}$ & (Percent) & $\begin{array}{l}\text { Number } \\
\text { of deaths }\end{array}$ & (Percent) & $\begin{array}{l}\text { Number } \\
\text { of deaths }\end{array}$ & (Percent) & $\begin{array}{l}\text { Number } \\
\text { of deaths }\end{array}$ & (Percent) \\
\hline $1-29$ & 2,155 & $(3.3 \%)$ & 27 & $(8.6 \%)$ & 887 & $(1.4 \%)$ & 15 & $(6.1 \%)$ \\
\hline $30 \sim 44$ & 6,372 & $(9.8 \%)$ & 41 & $(13.1 \%)$ & 1,980 & $(3.1 \%)$ & 24 & $(9.7 \%)$ \\
\hline $45 \sim 54$ & 4,857 & $(7.4 \%)$ & 61 & $(19.4 \%)$ & 2,543 & $(4.0 \%)$ & 33 & $(13.3 \%)$ \\
\hline $55-64$ & 10,630 & $(16.3 \%)$ & 63 & $(20.1 \%)$ & 7,107 & $(11.3 \%)$ & 35 & $(14.1 \%)$ \\
\hline $65 \sim 74$ & 18,288 & $(28.0 \%)$ & 65 & $(20.7 \%)$ & 15,157 & $(24.1 \%)$ & 62 & $(25.0 \%)$ \\
\hline $75+$ & 22,949 & $(35.2 \%)$ & 57 & $(182 \%)$ & 35,332 & $(56.1 \%)$ & 79 & $(31.9 \%)$ \\
\hline Total & 65,251 & $(100.0)$ & 314 & $(100.0)$ & 63,006 & $(100.0)$ & 248 & $(100.0)$ \\
\hline
\end{tabular}

cally that the Korean immigrant population in New York City is, on average, much younger than the White population. Among women, for instance, more than half of the Whites but fewer than one-third of Koreans died at age 75 or older. This, of course, is to be expected in a group of recently arrived immigrants, and very likely reflects a migration selection process.

Proportional mortality ratios for selected causes of death, adjusted for age, are shown in Table 2. Korean males showed a significant excess of viral hepatitis (PMR $=32$ ), cancer $(1.5)$, stroke (2.9), and external causes: accidents (2.0), suicide (3.5) and homicide (3.3). They had significantly reduced proportional rates of AIDS (0.1) and ischaemic heart disease (0.6). Korean women had significantly increased proportional rates of stroke (4.2) and accidents (3.2), and significantly reduced rates of IHD (0.8).

Despite the small numbers of cancer deaths (109 males, 81 females), distinct patterns emerged. Males and females both had significant excesses of stomach and liver cancer, and non-significant excesses of gallbladder cancer. There were 9 deaths among Korean women from breast cancer, which was significantly below expectation (PMR $=0.5)$. Pancreatic cancer was elevated in men (2.5) but not women. Lung cancer was not significantly different from expectation, and there were no cases of malignant melanoma, which is the fastest increasing cancer in many White populations.

\section{DISCUSSION}

Accurate assessment of the health status of immigrants is an important component of health and social servide planning, especially in New York City, where $28.1 \%$ of the population in 1990 were foreign-born salvo ot at. 1992), compared with $18.2 \%$ in 1970 . New York City has traditionally been a port of entry for many immigrant sroups, and received nearly one-sixth of all immigrants to the U.S. during 1984-1989, more than any other ciry (Salvo et al. 1992).

Over 271,000 Koreans immigrated to the U.S. during 1982-89, making them the fifth largest immigrant group in terms of new arrivals, after those from Mexico, Philippines, China, and Vietnam. About 20,000 came to New York City during that period, making Korea the seventh largest source of immigrants to the City. Only Los Angeles received more Koreans; other major cities selected by many new Korean-Americans were Washington, D.C., Chicago, and Anaheim.

The rapid growth in immigration of specific ethnic groups to New York makes population estimation difficult, even in census years. The 
Table 2. Proportional mortality ratios(PMRs) for selected causes of death, 1986 1990, among Korean migrants to New York City(US-born Whites $=1.00$ )

\begin{tabular}{|c|c|c|c|c|c|c|c|c|}
\hline \multirow[b]{2}{*}{ Cause, ICD } & \multicolumn{2}{|c|}{ No. Deaths } & \multirow[b]{2}{*}{ PMR } & \multirow[b]{2}{*}{$\begin{array}{l}\text { Confidence } \\
\text { Interval }(95 \%)\end{array}$} & \multicolumn{2}{|c|}{ No. Deaths } & \multirow[b]{2}{*}{ PMR } & \multirow[b]{2}{*}{$\begin{array}{l}\text { Confidence } \\
\text { Interval } 95 \%\end{array}$} \\
\hline & Us white & Korean & & & US White & Korean & & \\
\hline Tuberculosis, $010-018$ & 79 & 2 & 4.43 & $(0.5 \sim 14.4)$ & 28 & 1 & 6.59 & $(0.1-28)$ \\
\hline Septicemia, 038 & 589 & 2 & 0.82 & $(0.1 \sim 2.9)$ & 686 & 3 & 1.22 & $(0.2 \sim 3.5)$ \\
\hline AIDS, 042, 279.1 & 4194 & 2 & $0.06^{* * * *}$ & $(0 \sim 0.2)$ & 326 & 1 & 0.24 & $(0 \sim 1.3)$ \\
\hline Viral Hepatitis, 070 & 22 & 4 & $32.06^{* * * *}$ & $(10.8-102)$ & 16 & 1 & 12.14 & $(0.1 \sim 56)$ \\
\hline Cancer $140-208$ & 15997 & 109 & $1.48 * *$ & $(1.2 \sim 18)$ & 16356 & 81 & 1.03 & $(0.8-1.3)$ \\
\hline Nasopharynx, 147 & 34 & 1 & 5.16 & $(0.1 \sim 27.8)$ & 28 & 0 & 0.0 & \\
\hline Stomach, 151 & 512 & 21 & $9.42^{* * *}$ & $(59 \sim 146)$ & 369 & 19 & $14.31^{* * * *}$ & $(8.8 \sim 22.8)$ \\
\hline Colon, 153 & 1810 & 6 & 0.80 & $(0.3 \sim 1.7)$ & 1827 & 4 & 0.57 & $(0.2 \sim 1.5)$ \\
\hline Liver, 155 & 372 & 22 & $13.59^{* * * *}$ & $(8.6 \sim 20.8)$ & 282 & 9 & $7.42^{* * * *}$ & $(3.4 \sim 14.2)$ \\
\hline Gallbladder, 156 & 90 & 1 & 2.65 & $(0 \sim 139)$ & 146 & 1 & 1.85 & $(0 \sim 111)$ \\
\hline Pancreas, 157 & 749 & 8 & $2.47^{*}$ & $(1.1 \sim 49)$ & 907 & 3 & 096 & $(0.2 \sim 2.5)$ \\
\hline Lung, 162 & 4827 & 19 & 0.84 & $(0.5 \sim 1.3)$ & 3254 & 11 & 0.69 & $(0.3-1.2)$ \\
\hline Breast, 174 & & & & & 3362 & 9 & $0.52^{*}$ & $\left(0.2^{-} 1.0\right)$ \\
\hline Uterus, 179 & & & & & 186 & 0 & 0.0 & \\
\hline Cervix, 180 & & & & & 177 & 3 & 2.55 & $(0.5-7.3)$ \\
\hline Prostate, 185 & 1454 & 3 & 0.61 & $(0.1-1.8)$ & & & & \\
\hline Lymphatie, $200 \sim 202$ & 836 & 8 & 1.63 & $(08 \sim 32)$ & 644 & 2 & 0.56 & $(0.1 \sim 2.0)$ \\
\hline Benign tumors, $210 \sim 239$ & 253 & 1 & 0.74 & $(0 \sim 4,0)$ & 277 & 0 & 0.0 & \\
\hline Diabetes, 250 & 800 & 4 & 1.05 & $(0.3 \sim 27)$ & 900 & 3 & 0.80 & $(0.2 \sim 2.3)$ \\
\hline $\begin{array}{l}\text { Ischaemic heart } \\
\text { disease, } 410 \sim 414\end{array}$ & 21341 & 52 & $0.61^{* * * *}$ & $(0.5 \sim 0.8)$ & 23281 & $53^{-7}$ & $0.75^{*}$ & $(0.6 \sim 1.0)$ \\
\hline $\begin{array}{l}\text { Cerebrovascular } \\
\text { disease } 430-438\end{array}$ & $\ln 7$ & 21 & $2.85^{* * *}$ & $(1.8 \sim 4.3)$ & 2575 & 36 & $4.24^{* * *}$ & $(3.0 \sim 5.9)$ \\
\hline $\begin{array}{l}\text { Pneumonia and } \\
\text { Influenza, } 480-487\end{array}$ & 2341 & 8 & 0.90 & $(0.4-1.3)$ & 2847 & 7 & 0.79 & $(0.3 \sim 1.6)$ \\
\hline $\begin{array}{l}\text { Chronic Obstructive } \\
\text { Pulmonary } \\
\text { Disease, } 490 \sim 496\end{array}$ & 1707 & 4 & 0.62 & $(0.2-1.6)$ & 1573 & 0 & 0.0 & \\
\hline $\begin{array}{l}\text { Liver disease, including } \\
\text { Cirrhosis, } 571\end{array}$ & 1129 & 7 & 091 & $(0.4 \sim 1.9)$ & 492 & 3 & 0.91 & $(0.2-2.7)$ \\
\hline \multicolumn{9}{|l|}{ Childbirth, $660 \sim 669$} \\
\hline Accidents, E800 949 & & & $2.03^{* * *}$ & & 1 & 1 & 59.13 & \\
\hline Suicide, E950 - 959 & 1374 & 20 & $3.45^{* * *}$ & $(1.2-3.1)$ & 844 & 16 & $3.16^{* * *}$ & $(1.8 \sim 5.1)$ \\
\hline Homicide, E990 999 & 643 & 18 & $325 * * *$ & $(2.1 \sim 5.5)$ & 312 & 7 & 2.42 & $(1.0 \sim 5.0)$ \\
\hline Undetermined whether & 587 & 18 & 1.53 & $(1.9 \sim 5.2)$ & 157 & 4 & $2 \times 30$ & $(0.5 \sim 6.0)$ \\
\hline $\begin{array}{l}\text { accidental, homicide, or } \\
\text { suicide, E980 } 989\end{array}$ & 381 & 5 & & $(0.5 \sim 3.8)$ & 131 & 2 & 1.74 & $(0.2 \sim 6.6)$ \\
\hline Total deaths & 65251 & 314 & & & 63006 & 248 & & \\
\hline
\end{tabular}

${ }^{*} \mathrm{P}<0.05 ;{ }^{* *} \mathrm{P}<0.01 *^{* * *} \mathrm{P}<0.001$ 
1900 census listed 69,718 persons of Korean ancestry who resided in New York City, making them the third most populous group of East Asian origin, after Chinese (238,919) and Asian Indians (94,590). The rate of increase may be gauged to some extent by examining the numbers of births for which the certificate item "Descent or Origin" (pre-1988) or "Ancestry" (1988-90) for the mother indicated Korean. Between 1987 and 1989 the number of such births in New York City increased from 1,120 to 1,236 , or by about $5 \%$ per year (New York City Department of Kealth, 1991).

An independent estimate of population growth can be made from Immigration and Naturalization Serwice figures, which show an average annual influx of Koreans of nearly 2,700 between 1986 and 1989 , or roughly $5 \%$ of the population already resident each year.

This agrees well with the growth in births, and corresponds to a nominal population growth of $18 \%$ during the period covered by this mortality analysis; however, little is known of subscquent out-migration. Furthermore, census and immigration data cannot be directly intermingled, because an unknown number of so-called immigrants are counted when they change their status, rather than at the time of arrival, and may actually have been in the U.S. for some time three years on average).

For these reasons, proportional rates are methodologically attractive, since they are not dependent upon denominators. However, PMR' $s$ have two main drawbacks. First, since all proportions must add to $100 \%$, a PMR for a specific cause may appear to be elevated only because some other important cause of death is low. This remarix applies especially to heart disease and total cancers, the two leading causes. Secondly, PMR's are not estimates of relative rates, relative risls, or other population parameters. They represent only general mortality patterns, and must be interpreted accordingly.

Despite the absence of reliable death rates within Korea itself, Kim at al. (1989) noted that the overall pattern of death in Korea has begun to shift from the infectious disease pattern common to developing countries to the chronic disease pattern of industrialized countries. The World Health Organization estimated for Korea that circulatury diseases other than stroke accounted for $17.4 \%$ of all deahs. Cancer was the second leading cause (16.7\%), and stroke the third $(13.0 \%)$, followed by accidents, chronic liver disease, and tuberculosis (World Health Organization, 1990).

The appearance of stomach cancer as a leading malignancy in boti sexes is in agreement with recent reports from a populationbased registry recently established in Korea (Kim et at. 1989). The clevated proportional rate of liver cancer is also consistent with the Korean cancer data, as is the 2.6 fold increase in cervix cancer and the deficit in breast cancer.

The greatly elevated proportional death rates in both sexes from viral hepatitis and liver cancer among Korean immigrants to New York City serve to underscore the need for serologic surveys for hepatitis $B$ wirus infection within this group. In Korea, high positivity rates for hepatitis $B$ surface antigen (HBsAg) as well as serologic evidence of past and present hepatitis $B$ virus infection have been reported in some populations (Lee et $d$. 1989). Higher carrier rates or hepatitis B surface antigen (HBsAg) have already been established for Chinese residents of New York City as well as in Los Angeles (Tong ot at. 1991), where the incidence of liver cancer is higher than among other ethnic groups (Bernstein and Ross, 1991).

Liver and cervix cancer rates were also elevated in Koreans living in Japan (Kim, 1984; Ubukata at al. 1986: Kono ot al. 1987), but. stomach cancer was not; this is not surprising, however, as the death rate from stomach cancer in Japan, which was used as the reference rate for the cited studies, is at least five times that of U.S. Whites. Liver, stcmach, and cervical cancer were recently reported to be elevated in Chinese immigrants to New York City (Stellman and Wang, 1994).

The single death from cancer of the nasopharynx in a Korean male, five times the expected number; is unusual, since nasopharyngeal cancer in Asians is ordinarily associated with southern China (King of al. 1985) and 
an excess has not been previously reported in Koreans.

Several other observations are of special interest within the context of public health in New York City. Tuberculosis is a resurgent disease which has particularly afflicted immigrant groups. In the present study there were only three tuberculosis deaths (two men, one woman), but these were four to seven times the expected numbers. This should raise a signal that immigrants be more carefully screened for $T B$, and that public health measures to treat newly found cases and to prevent further spread within the Korean community should be rigorously applied. On the other hand, there were fewer cases than expected of AIDS, which is the third leading canuse of death in New York City as a whole (Thomas et al. 1993). The Asian population of New York has previously been reported to be at lower risk than other groups, which is entirely consistent with the small number of AIDS deaths observed in this study.

One Korean woman died of childbirth-associated causes, a sixty-fold increase. While not statistically significant, it is nonetheless alarming, especially since the maternal mortality rate has been declining for many years, while the birth rate has increased markedly. The annual number of maternal deaths among all New Yorkers has not exceeded thirty since 1986.

Finaly, we made a disturbing observation with respect to external causes of death: accidents, homicide, suicide. Even after adjustment for age, the proportional rates for these three causes, individually or combined, were two to three times the expected rates. PMR's were consistently elevated across all age-sex strata. Similar observations have been made for Koreans of both sexes in Japan (Shinohara et al. 1990) and for Chinese immigrants to New York City (Stellman, unpublished). These observations, together with recent evidence that acculturative stress is strongly associated with symptoms of depression in Korean immigrant women in New York (Shin, 1994), point up the need for further investigation into the reasons for violent deaths among recent immigrants.

\section{REFERENCES}

Bernstein L, Ross RK: Cancer in Los Angeles County. A Portrait of Incidence and Mortality 1972-1987. Los Angeles, University of Southern California, 1991

Breslow NE, Day NE: Statistical Methods in Cancer Research, Volume II. The Design and Analysis of Cohort Studies. Iyon, International Agency for Research on Cancer, IARC Scientific Publications No. 82,1987

Frerichs RR, Chapman JM, Maes EF: Mortality due to all causes and to cardiovascular diseases among seven race-ethnic populations in Los Angeles County, 1980. Int I Epidemid 13: 291298,1984

Kim IS, Suh I, Oh HC, Kin BS, Lee X: Incidence and survival of cancer in Kangwha County (1983-1987). Yonsei Med J 30: 256-268, 1989

Kim OK: Estimation of adult mortality in Korea; levels, trends, and socioeconomic differentials. $J$ Biosoc Sci 18: $347-356,1986$

Kim YS: Cancer mortality of the Korean population in Japan, 1968-1977. Int I Etridemiol 13: 11 14, 1984

King H, Li JY, Locke FB, Pollack ES, Tu JT: Patterns of site-specific displacement in cancer mortality among migrants: the Chinese in the United States. Am I Pubic Foall 75 : 237-242. 1985

Kono S, Isa AR, Ogimoto I, Yoshimura T: Cause specific mortality among Koreans, Chinese, and Americans in Japan. Int $J$ Epidemiol 16:415419,1987

Lee SH, Lee BK, Lee KM, Oh KS, Inoue O, Seiji $\mathrm{K}$, Ideka $\mathrm{M}$ : Hepatitis $\mathrm{B}$ virus infection among women in a shoe factory in Korea. Asia Pac $J$ Public Health 3: 145-149, 1989

Ministry of Health and Social Affairs: Five Years' Report for Cancer Registry Programme in Republic of Korea (II), July 1, 1982 - June 30, 1987. Seoul, Ministry of Health and Social Affairs, 1988

New York City Department of Health: Summary of Vital Statistics, 1969. New Yox, New York City Department of Health, 1991

Rothman KJ, Boice JD: Epidemiologic Analysis with a Programmable Calculator. MA. Brookline, Epidemiology Resources, Inc. 1982

Salvo J, Ortiz R, Vardy F: The Newest New York- 
ers: An Analysis of Immigration into New York City in the 1980's. New York, New York City Department of City Planning, 1992, 55, 775

Seel DI: Observed cancer incidence in Southwest Koroa. Cancer 46: 852-858, 1980

Shin KR: Psychosocial predictors of depressive symptoms in Korean-American women in New York City. Women Health 21: 73-82, 1994

Shinohara S, Kono S, Ahn YO, Shigematsu T: Cancer and other causes of death among Koreans in Fukuoka, Japan, 1976-1986. Jpn J Cancer Res 81: $866.870,1990$

Stellman SD, Wang QS: Cancer mortality in Chinese immigrants to New York City: Comparison with Chinese in Tianjin and with United States-born Whites. Cancer 73: 1270-1275, 1994

Thomas PA, Weisfuse IB, Greenberg AE, Bernard GA, Tytun A, Stellman SD: Trends in tho first ten years of AIDS in New Yor City. Am $J$
Epidemiol 137: 121-133, 1993

Tong MJ, Schwindt RR, Lo GH, Co RL: Etiology, Pathology, and Treatment of Hepatocellular Carcinoma in North America. In Tabor $\mathrm{E}$, DiBisceglie A M, Purcell R H, Eds. Etiology, Pathology, and Treatment of Hepatocellular Carcinoma in North America. TX, Houston, Gulf Publishing Co., 1991, 15-23

Ubukata T, Oshima A, Fujimoto I: Mortality among Koreans living in Osaka, Japan. Int J Epiderniol 15: 218-225, 1986

Ubukata $T$, Oshima A, Morinaga $K$, Hiyama $T$, Kamiyama S, Shimada A, Kim JP: Cancer patterns among Koreans in Japan, Koreans in Korea, and Japanese in Japan in relation to life-style factors. Jpn J Cancer Res 78: 437-446, 1987

World Health Organization: 1990 World Health Statistics Annual. Geneva, World Health Organization, 1990 